\title{
Artist-Teachers' In-action Mental Models While Teaching Visual Arts
}

\author{
Gila Russo-Zimet \\ Correspondence: Gila Russo-Zimet, Levinsky College of Education, Tel Aviv, Israel. \\ Received: March 1, 2017 \\ Accepted: April 13, 2017 \\ Online Published: April 23, 2017 \\ doi:10.11114/jets.v5i5.2378 \\ URL: https://doi.org/10.11114/jets.v5i5.2378
}

\begin{abstract}
Studies have examined the assumption that teachers have previous perceptions, beliefs and knowledge about learning (Cochran-Smith \& Villegas, 2015).

This study presented the In-Action Mental Model of twenty leading artist-teachers while teaching Visual Arts in three Israeli art institutions of higher Education. Data was collected in two stages: videotaping of art lessons and stimulated recall interviews.

Data was analyzed in three steps: Three artists-teachers' data was analyzed and based on the results, explicit (behavioral) and implicit (mental models) categories were built. In the second step, all the categories were analyzed in accordance to the three teachers' data. In the third step, data collected only from the artist-teacher that used different lesson patterns in the same lesson was analyzed.

The teacher's mental model is influenced by the subject matter - visual arts. As evidence, the general mental model (Mevorach \& Strauss, 2012) does not include all the components of the in-action mental model of teachers teaching visual arts. The characteristics of various types of subject matters may contribute to the understanding of the in-action mental model of teaching, and understand how these subject matters influence the in-action mental model, and the Teaching Model as a whole.
\end{abstract}

Keywords: artist-teachers, in-action mental model, visual arts, teaching, learning

\section{Introduction}

Many studies have examined the role that teacher preparation in the process of teaching and learning, under the assumption that teachers have previous perceptions, beliefs and knowledge developed over time and that the learning begins prior to the formal teacher preparation (Cochran-Smith \& Villegas, 2015).

Many factors shape perceptions and viewpoints, and they are both personal and professional. Teaching is a result of previous teaching experiences and it becomes the source of new knowledge for teachers. The roots of teachers' behavior is in social and institutional practices and it is only within this social environment that practices can be interpreted, and the way the teachers themselves make sense of it can be understood. Practices are in part grounded in tacit representations and mental models - perception, action and value schemes - which have been automated and naturalized in such a way that they are never questioned (Lee \& Johnson, 2007; Kitayama \& Cohen, 2010).

This article focuses on artist-teachers' teaching visual arts. Its main goal is to understand the relationship between teaching practices, and teachers' implicit knowledge-mental models about the way learning takes place. In other words, what practices can tell us about the way teachers' implicit mental model motivates the way they teach in the classroom by explaining how teachers are inclined to think (mental models) and act (teaching). This study analyzed artist-teachers' instruction of visual arts in institutions of higher education and their retrospective reflection on that teaching, with the aim of inferring about the teachers' implicit in-action mental models for teaching visual arts and how these models effect their teaching actions in the classroom.

\section{Literature Review}

The assumption underlying this study was that each teacher holds an idiosyncratic mental model for teaching - a hidden, dynamic psychological entity that organizes the way he or she understands (Lynam \& Brown, 2012; Manrique \& Abchi, 2015; Mevorach \& Strauss, 2012). This model is activated (in-action) while they are teaching. Mental model in action informs teachers' knowledge about thinking: it explains how mental models arise from the idiosyncratic methods of developing the dialogue and relationships necessary to guide thinking. Mental models are purposeful cognitive 
structures that have a process/product nature. They also have several functions that enable them to store data and enact strategies to generate outcomes.

Researchers contend that empirical scrutiny of psychological and cognitive processes involving mental models comprising personal intuitions, knowledge, theories, beliefs, and metaphors - can contribute significantly to the understanding of teachers' thinking processes that underlie explicit behavior in the classroom (for example, Berliner, 2005; Strauss, 2001).

\subsection{In-action Mental Models}

A mental model is a hidden, dynamic psychological entity that organizes the way individuals understand and act in the outside world (Jones, Ross, Lynam, Perez \& Leitch, 2011; Johnson-Laird, 1983, 2001; Mayer, 1983; Mevorach \& Strauss, 2012; Moray, 1999; Norman, 1983; Palmunen, Pelto, Paalumäki \& Lainema, 2013).

Thus, mental models are a product of human beings' relations with their surroundings. Every person holds a set of thoughts, feelings, and beliefs concerning each phenomenon that he or she seeks to understand or with which he or she interacts.

The literature distinguishes between "declarative" mental models, which are expressed when individuals verbally describe their thoughts in addition to their actions, and in-action mental models that are deduced from the individuals' actions. In-action referred to the fact that the mental model was activated during the actual teaching activity when they actually practice teaching (Lynam, \& Brown, 2012).

Schön (1983, 1987, 1988) compared teachers' knowledge when they actually practice teaching (in-action) versus knowledge when they talk about their actual teaching (on-action). In another world, the mental model would have been activated during the actual teaching activity.

In an early study, Schutz (1970) contrasted visible, identifiable actions (explicit) with hidden, concealed actions (implicit) that may be identified only by revealing their underlying cause, motive, intention, or belief. Researchers have asserted that teachers' implicit mental models that are activated during teaching are connected to teachers' pedagogical decisions. In a prior research in the field of teachers' mental model in-action, Mevorach (2010) proposed that teachers share a common general in-action mental model for teaching based on teacher-student-teacher interactions, which direct the teaching from the teacher to the students. The units described were as follows: (a) meta-assumptions like repetition stimulates and helps preserve existing knowledge; (b) cognitive processes such as listening and preserving; (c) cognitive goals like directing and focusing listening; and (d) basic assumptions such as Demo is geared toward identifying and linking to evaluate the applicability of the general in-action mental model in specific settings.

Haim, Strauss \& Ravid (2004) found the same mental model in their study. They observed foreign language teachers and found that the in-action mental model is also based on teacher-student-teacher interactions. In another study, Mevorach and Strauss (2012) examined the general in-action mental model among educators teaching a specific subject matter, pedagogy instructors, during college courses and among field supervisors while delivering feedback to the students. Findings showed that the general in-action mental models (based on teacher-student-teacher interactions), were activated by educators while teaching the course, but feedback from the students in the classroom showed they use a different mental model and that the general mental model found in previous studies was not suitable to this case. Mevorach and Strauss (2012) proposed that it is possible to describe the same person's teaching through several mental models of the learning process, which guide the teacher's teaching process.

Before presenting our methodology for uncovering artist-teachers' in-action mental models, we will first discuss these aspects of the visual arts discipline.

\subsection{Characteristics and Challenges of Visual Arts Instruction}

The arts may offer particular insights into phenomena that are of interest to educational researchers (Donoghue, 2009). Art is a holistic discipline that combines observation of art with experiential creative processes, and which connects the real world and the objects represented in the oeuvres. Thus, the arts provide access to forms of experience that are a lot less accessible or even inaccessible through other representational forms (Eisner \& Day, 2004). Moreover, discourse about the arts, such as occurs in a visual arts classroom, offers enormous potential for exposing values and characteristics of the participating individuals (Huss, 2008).

Teaching of visual arts does not resemble teaching of many other disciplines, such as science or mathematics. Science teachers instill knowledge and concepts, which they perceive as unified, logical, and canonic, and they encourage students to produce and examine rules, claims and arguments for understanding reality (Yaakobi \& Sharan, 1985). In contrast, art teachers encourage students to use their existing personal knowledge and concepts, much like in the literary arts, but visual art teachers also encourage students to produce art images based on observation and sensation (Ball \& Forzani, 2011; Ball, Thames \& Phelps, 2008; Vosniadou, Baltas, \& Vamvakoussi, 2007). Espousing an existentialist 
approach, Eisner (2004) claimed that art is a process that activates skills and leads to insights that differ from the scientific method, including an emphasis on meaning, striving for change, and even an affinity for the mystical and the metaphysical. Thus, the visual arts encompass several unique aspects: the language of art, the role of observation in art, and the centrality of personal practical experimentation.

\subsubsection{Language of Art}

A work of art represents the relations between the objects it describes and other symbols appearing therein (Goodman, 1976). Every work of art, regardless of genre, contains one or more statements regarding the outer and/or inner world, which are expressed through fundamental components such as dots, lines, spots, surfaces, colors, textures, compositions, and images - namely, the signs and symbols of visual language or visual grammar. The language of art also contains signs and combinations that are culture, time, and space-dependent (Braden \& Hortin, 1982). Optimally understanding the statements being expressed by an artwork - which is an independent entity constructed, studied, and acquired by the artist - requires an understanding of the language code of art (Goodman, 1976). Visual literacy is defined as a collection of visual abilities that enable people to discern visual phenomena in the environment and interpret them via natural visual symbols or human actions (Flood, Brice, \& Lapp, 1997).

\subsubsection{Observation}

Art studies develop students' ability to observe the surrounding world and think about it creatively (Eisner \& Day, 2004). The connection between an artwork and the observer's experience of it is achieved through the observer's perception, experiences, inner search, and interpretation processes - namely, through observation of the artwork's language (e.g., expressed in colors, symbols, and images), which can serve as the basis for analysis and critique of a visual artwork's design, style, format, and so on. Works of art allow for multiple interpretations, and observations can trigger personal memories, link up to existing knowledge, as well as elicit diverse new experiences that may influence the observer's interpretations. As much as visual arts reflect the societal and cultural contexts in which the artist is immersed, observation also enables construction of narratives that reflect sociocultural events and beliefs (Langer, 1969).

\subsubsection{Experimentation}

A chief focus in visual arts instruction is personal practical experimentation with various artistic media via a process of active learning, doing, and thinking. Through hands-on manipulation, students can think, feel, and create. The artwork serves as the text, and students use materials (e.g., paper, paintbrush and paints) designed to mediate between the student artist and his or her creation.

Art philosophers deal with the materials that influence the artwork and the artist's understanding of themselves and reality; using materials, the artist creates connections between the real world and the objects represented in the artwork (Arnheim, 1966, 1974, 1989, 1992; Bresler, Grauer, \& Powell, 2014). The work of art reveals a new entity by translating reality using materials and their constraints (e.g., size, dimensions, and physical properties). Thus, several unique features that require comprehension and consolidation on the part of the instructor characterize visual arts instruction. It is challenging to be an artist-teacher. The teachers are leading artists. The students of the participants in the present study are aspiring artists and the artist-teachers are trying to teach them to become artists.

The study presented here analyzed artist-teachers' instruction of visual arts in institutions of higher education and their retrospective reflection on that teaching, with the aim of inferring about the teachers' implicit in-action mental models for teaching visual arts and how those models reciprocally and dynamically influence and are influenced by the teachers' own explicit behaviors and students' behaviors.

\section{Method}

\section{a. Participants}

The sample comprised of twenty leading artists working as visual arts teachers in three Israeli art institutions of higher Education (Bezalel Academy of Arts and Design, Hamidrasha School of Art at Beit Berl College and Seminar Hakibutzim College). Locating them was done in two ways: 1) approaching the supervision department in The Ministry of Education, responsible for awarding scholarships to artists that teach visual arts. Each year the Ministry of Education awards five scholarships to artists, painters, sculptures and architects so that they could teach adolescents and adults for one or two years; 2) approaching the heads of institutions that teach visual arts.

The participants came from different backgrounds (gender, place of teaching, education, age and seniority) that teach a variety of subjects in visual arts (painting, sculpting and photography) in order to validate the results. The assumption was that if a model common to teachers that teach sculpting, painting, photography and design would be found, and if it would not be connected to gender, education and seniority, it would be acceptable to claim that the subject matter, visual arts, does in fact influence the teacher's mental model about his students` learning. 
The sample comprised of twenty artist-teachers, twelve men, eight women, five teach in Bezalel Academy; ten teach in Beit Berl College; two teach in teacher training institutions and three teach in "Alon" high school. Their ages ranged from 29 to 65 (average age: 43.9) and they all engaged actively in different fields of visual arts and displayed their work in exhibitions, galleries, and museums across Israel and the world. Participants had an education level ranging from high school graduates to Ph.D. holders (average education years - 17.40) and teaching experience ranging from two to thirty years (seniority average: 12.6). The presidents of the institutions gave their permission to faculty members to participate in the study, and consent was obtained from all the artists-teachers. Students attending the visual arts classes gave written consent to be videotaped and for their lessons to be analyzed.

\section{b. Procedure}

To expose the proposed dynamic circular in-action mental model for visual arts teaching in real time in class, we videotaped artist-teachers' full lessons and then asked them in follow-up interviews to retrospectively reconstruct their teaching behaviors and thinking. This research utilized a mixed-methods paradigm that included qualitative-interpretive and quantitative concepts and methods (Maxwell \& Loomis, 2003), based on grounded theory (Charmaz, 2005) and methodology developed in previous research on in-action mental models (Haim et. al., 2004; Strauss, 2005).

To collect a rich data set depicting artist-teachers' explicit teaching behaviors and implicit mental models, data were collected in two stages: videotaping of art lessons and stimulated recall interviews. Each of the artist-teachers was videotaped while teaching one visual arts lesson (duration 3-4 hours). A researcher used one video camera focused on the artist-teacher in the classroom. The lesson's videotaping began the moment the artist-teacher entered the classroom and ended the moment he or she left the class. Videotaping allowed minimal intervention in the classroom, while providing a comprehensive perspective and enabling retrospective analysis. Moreover, this method allowed repeated viewing, alone and with the teacher. This process enabled the teacher to undergo a reflective process about the lesson itself (Bower, et. al, 2011; Chaterise \& Smardon, 2013; Danielowich, 2014; Ratcliff, 2003).

The next stage included an individually administered stimulated recall interview, which was conducted with each participant within a week of the videotaped lesson in a quiet setting at the art teacher's home as well as an interview by the researcher.

Using this interview method, while watching their own-videotaped lesson on a laptop computer, participants were asked to reconstruct their teaching methods and describe their thoughts during the lesson, with the option of pausing and rewinding the tape at any time (Bishop, 2005; Denzin \& Lincoln, 2005a). Interviews lasted 30-45 minutes. The interview while watching their own videotaped was used in order to properly understand the intentions, motives and intentions of the teacher during the lesson.

It is imported to state that the data collected from the interview helped the researcher to build categories during the analysis in the class, understand the intention of the teachers' choices and divide them into levels and categories.

\section{c. Data Analysis}

Data was analyzed in three steps: the first step of analysis was to create levels and categories from three participants'. For each of the three artists-teachers the videotaped lesson and the interview were used. These participants were selected to represent gender (two men, one woman), different fields of visual art (painting, video art and sculpting) and different institutions (Beit Berl, Bzaleel and Kibutzim College).

The analysis comprising the explicit (behavioral), and the implicit (mental models), as follows: (1) in the explicit level, overt teaching behaviors enacted by participants (artist-teachers) during the lesson and were classified into categories: (1) Lesson pattern; (2) Segment (according to verbal discussion and nonverbal); (3) Acts (according to discourse mode), and (4) Content.

At the implicit level, covert thinking by participants - namely the artists-teachers' in-action mental model - was revealed indirectly from the videotaped lesson. This level was classified into three categories: meta-assumptions according to the knowledge skill and according to teaching method, goals and process.

In the second step of analysis, all the categories that were analyzed according to the three teachers were interred to the system software that was used to analyze all twenty artists-teachers. The system is The Observer 4.0 software platform (1997), which was programmed to enable classification of videotaped and transcribed data according to the category (Noldus, et. al., 2000). The frequency was analyzed according to the categories of the explicit and the implicit levels. The Observer software enabled quantitative data analysis including frequencies (Noldus, Trienes, Hendriksen, Jansen, \& Jansen, 2000). Credibility was examined regarding the coding categories. The researcher and a Master's Degree student who majors in psychology analyzed one lesson. The researcher and the M.A. student independently observed and coded the same randomly selected videotaped lesson. Inter-judge reliability reached 87 percent agreement. 
In the third step of analysis, an artist-teacher that used all three patterns in one lesson to characterize the in action mental model was detected.

All the elements were organized in a table that presents all the different components identified in the lesson. Table 1 presents the analysis made on the three artists-teachers, which was the basis to the analysis of all the other participants, as well as an examination of the frequency in which the components were discovered in their lessons and to build the theory about the in action mental model of art teachers teaching visual arts.

Table 1. Explicit (behavioral) and implicit (mental) categories yielded by content analysis

\begin{tabular}{|c|c|c|c|c|c|c|c|c|}
\hline \multicolumn{5}{|l|}{ Explicit } & \multicolumn{4}{|l|}{ Implicit } \\
\hline \multirow[t]{2}{*}{ Lesson pattern } & Segment & & Acts & Content & Meta-assumption & & Goal & Process \\
\hline & Verbal & Nonverbal & $\begin{array}{l}\text { Discourse } \\
\text { mode }\end{array}$ & & Knowledge/skill & $\begin{array}{l}\text { Teaching } \\
\text { method }\end{array}$ & & \\
\hline Creative workshop & $\begin{array}{l}\text { Discussion or } \\
\text { debate }\end{array}$ & Observation & $\begin{array}{l}\text { Asking } \\
\text { questions }\end{array}$ & Form-related & Evaluative ability & $\begin{array}{l}\text { In-depth } \\
\text { observation }\end{array}$ & observational & Identification \\
\hline $\begin{array}{lr}\begin{array}{l}\text { Analysis } \\
\text { critique }\end{array} & \text { and } \\
\text { students' } & \text { artwork } \\
\text { products } & \\
\end{array}$ & $\begin{array}{l}\text { One-on-one } \\
\text { dialogue }\end{array}$ & Experimentation & $\begin{array}{l}\text { Information } \\
\text { provision }\end{array}$ & Contextual & Technical ability & $\begin{array}{l}\text { Ongoing } \\
\text { discourse }\end{array}$ & Technical & Focus \\
\hline \multirow[t]{5}{*}{$\begin{array}{l}\text { Discussion of } \\
\text { art-related topics }\end{array}$} & Monologue & & Feedback & Technical & $\begin{array}{l}\text { Organizational } \\
\text { ability }\end{array}$ & $\begin{array}{l}\text { Individual } \\
\text { experience }\end{array}$ & Meta-cognitive & Connection \\
\hline & & & Demonstration & Emotional & Emotional ability & & Affective & $\begin{array}{l}\text { Increasing } \\
\text { attention }\end{array}$ \\
\hline & & & & Reflective & $\begin{array}{l}\text { Observational/ } \\
\text { Visual abilities }\end{array}$ & & & Reflection on \\
\hline & & & & & $\begin{array}{l}\text { Knowledge about } \\
\text { arts }\end{array}$ & & & reconstruction \\
\hline & & & & & & & $\begin{array}{r}\text { Ref } \\
\text { Elic } \\
\text { Creation of in } \\
\text { En }\end{array}$ & $\begin{array}{r}\text { Arousal } \\
\text { ecting difficulties } \\
\text { Preservation } \\
\text { ing introspection } \\
\text { ividual processes } \\
\text { Expansion } \\
\text { tional regulation } \\
\text { Review } \\
\text { Identification }\end{array}$ \\
\hline
\end{tabular}

\section{Results}

\subsection{The Explicit Level: Artists-Teachers' Behaviors}

Table 1 presents the explicit (behavioral) and implicit (mental) categories yielded by the content analysis. Overt teaching behaviors enacted by artists-teachers in the videotaped lessons were classified into these categories: activities, segments, contents, discourse modes.

\subsubsection{Lesson Patterns}

As seen in Table 1, the lesson patterns are: Creative workshop, Analysis and critique of students' artwork products and Discussion of art-related topics. The segment was defined as a single verbal or nonverbal event that involved the artist-teacher over a discrete time unit within the lesson (measured for duration). The three verbal segment types included: (a) discussion or debate on various topics, (b) one-on-one dialogue, occurring when the teacher held a discourse with only one student, initiated either by the teacher or the student; and (c) monologue, referring to the teacher's continuous, unidirectional, one-sided discourse about an art concept, term, or topic.

The two nonverbal segment types included: (a) observation, where the teacher asked students to use the visual modality to focus attention on students' own artworks, in order to form an impression of it; and (b) experimentation, referring to the creative artistic process assigned by the teacher, through which students acquired skills and familiarity for working with varied art materials and techniques.

Acts-Discourse modes. Content analysis yielded four different modes of discourse used by artists-teachers during the lesson: (a) asking questions; (b) providing information; (c) giving feedback; (d) demonstrating.

Contents modes. As seen in Table 1, analysis yielded five different contents used by artists-teachers to create meaning during the lesson: (a) form-related (e.g., composition, color, line); (b) contextual (cultural, environmental influences);

(c) technical (techniques for working with materials); (d) emotional (involvement in the creative process); and

(e) reflective (understanding the process) contents (see Table 1).

As seen in Table 1, three general types of teaching lesson pattern were conducted over substantial enduring time units during the lessons. Following is a table presenting the average relative duration of each lesson pattern. 
Table 2. Average relative duration of each lesson segment

\begin{tabular}{rrr}
\hline standard deviation & average & lesson pattern \\
\hline .38 & 39. & $*$ analysis and work audit \\
\hline 41 & 38. & $* *$ workshop management \\
\hline .31 & 23. & $* * *$ general description of art \\
\hline
\end{tabular}

According to Table 2, it appears that across all classes a reference to the three lesson pattern of the lesson was found: analysis and critique of students' artwork products, workshop management and discussion of art-related topics.

It can also be seen from Table 2 that the average duration of the analysis and feedback as well as workshop management are almost equal and that the average duration of the general description of the art is lower than the other segments in the overall duration of the lessons. The duration of the teacher and the students was also examined in each lesson pattern.

A general discourse overview is presented here. The average in each segment of the lesson emphasizes that discourse is conducted 93 percent of the time in reviews, 90 percent of the time in general, and 82 percent of the time in workshops.

The managing time during the lesson with respect to the teacher and the students in was examined and presented in Table 3.

Table 3. Averages and relative deviations for managing time during the lesson - teacher and student according to the relative duration

\begin{tabular}{rrrrrrr}
\hline & general & \multicolumn{3}{c}{ workshop } & \multicolumn{2}{c}{ review } \\
\hline $\begin{array}{r}\text { relative } \\
\text { deviation }\end{array}$ & average & $\begin{array}{r}\text { relative } \\
\text { deviation }\end{array}$ & average & $\begin{array}{c}\text { relative } \\
\text { deviation }\end{array}$ & average & discourse \\
\hline .24 & 29. & 21. & 33. & 21. & 35. & students \\
\hline .28 & 61. & 26. & 49. & 18. & 58. & teachers \\
\hline
\end{tabular}

Table 3 shows that in the segments review, workshop and general (this is how these elements will be referred in short), the average duration of the discourse is higher than the average duration of student discourse. The relative duration of the teacher discourse in the workshop is lower than in the review and the general, and the average duration of a relative student discourse is higher in the reviews than in the workshop and the general.

\subsubsection{Correspondence among Activities and Segments}

What portion of the lessons, on average, was dedicated to each of these explicit behaviors? In an analysis of the average higher duration dedicated by the teacher in the lesson different acts stood out. The acts in each lesson pattern will be presented (note: all the acts during the lesson were examined, but reports about organizational acts such as students organizing during class, questions and requests made by the students that do not relate directly to the research subject, regulations and general information will not be presented).

(a) Creative workshop acts, where the artist-teacher assigned creative tasks using various materials and then observed and guided the students. It was found that the relative high average duration was given to the following acts: instruction by conceptual and reflective expansion of the required work (0.73), feedback on technicalities in the work (0.37), and instruction regarding materials and ways of construction (0.35); (b) Analysis and critique of students' artwork products, where the artist-teacher critically analyzed students' works by means of class discussion. It was found that the relative high average duration was given to the following acts: silent observation of the work (0.62), feedback on technicalities in the work (0.35), and positive feedback on the student's work (0.32); and (c) Discussion of art-related topics, where the artist-teacher and students talked about various theoretical issues related to art history and about diverse topics related to art and the artist profession. It was found that the relative high average duration was given to the following acts: giving out information about the artist, the work, expressing the teacher's personal opinion, commentary etc. (0.43), and silent observation of various artists' creations (0.32).

\subsubsection{Correspondence among Lesson Pattern-acts and Segments}

Unsurprisingly, links emerged between the various categories of the teaching model's explicit level, thereby supporting the content analysis scheme. First, during creative workshop activities, experimentation with materials was the most prevalent segment; the most prevalent content mode was dealing with techniques for working with materials; second, during reviewing activities, observation and discussion segments were most prevalent, reflection was the most prevalent content mode. Third, during teaching of art-related topics, the most prevalent segments were discussion, monologue, and observation; the context was the most prevalent content mode.

So far, findings about implicit behaviors observed during the lessons were presented in order to understand the mental model of teachers about their understanding of how teaching occurs. This study supports the literature that found that the teacher's mental model includes meta-assumptions about learning. The commentary is based on previous research made on mental models of teachers, knowledge about study programs in the field of visual art, interviews with the 
teachers that led the researchers to understand what lays in the basis of their perceptions and verify this information, and the lesson itself.

The mental model includes meta-assumptions regarding the discipline and the methodology, goals the teacher aims to achieve in the lesson and processes the teacher wishes to operate during the lesson pattern.

\subsection{The Implicit Level: Artists-Teachers' In-action Mental Models}

The analysis includes six meta-assumptions regarding contents and four meta-assumptions regarding discourses oriented at ways/methodologies. The artist-teachers' in-action mental models were revealed indirectly from the videotaped lesson. The content analysis yielded two categories for classifying teachers' implicit, covert thinking: meta-assumptions and goals.

\subsubsection{Meta-assumptions}

Meta-assumptions express the understanding of the teacher's mind. The data analysis indicated that the artists-teachers' meta-assumptions with respect to visual arts instruction could be classified into two categories - prerequisite student knowledge/skills and required teaching methods.

\subsubsection{Prerequisite Student Knowledge/Skills}

Table 4. Artist-teachers' meta-assumptions about visual arts students' prerequisite knowledge/skills in descending order of utterance/behavior frequency $(\mathrm{N}=20)$

\begin{tabular}{llll}
\hline & Meta-assumed knowledge/skill area & Frequency & Percentage \\
\hline 1 & Evaluative ability & 866 & 30.8 \\
2 & Technical ability & 693 & 24.6 \\
3 & Organizational ability & 464 & 16.6 \\
4 & Knowledge about arts & 362 & 12.5 \\
5 & Emotional ability & 278 & 9.8 \\
6 & Observational/visual ability & 159 & 5.7 \\
\hline & Total & 2,822 & 100 \\
\hline
\end{tabular}

As seen in Table 4, the analysis yielded six meta-assumptions regarding students' required knowledge and skills that effective visual arts teachers must develop in students:

Evaluative ability (referring to skills for reflection difficulties eliciting introspection) (30.8 percent, f-866), for example, teacher verbalizations such as, "I wanted to make them think about connections that stir instability". During the interview the teachers says, "They must have evaluative ability".

Technical ability (skills for working with materials) (24.6 percent f-693). For example, the teacher says, "You cannot disassemble the work. Try doing it this way" (demonstrates to the student); or another example: "You will have to think of how to work with dark and light pencils and try to think about their thickness".

Emotional ability (identification of feelings, affective regulation) (9.8 percent f-278), for example, when a teacher asks, "When you see the paintings do you feel like making a connection? Are the connections strong? What do they make you feel?" during the lesson, this implied a meta-assumption that teachers must develop visual arts students' emotional ability.

Observational/visual abilities (skills for focus, identification and increasing attention) (5.7 percent f-159), the teacher says, "Try to forget what you know and focus only on what you are looking at".

As well as Knowledge about arts (referring to connection and generalization to intertextuality, culture and art history) (12.5 percent f-362). For example, the teacher says, "I want to show you Rauschenberg's drawings", or, "I would like to mention an exhibition that was displayed a few months ago".

\subsubsection{Required Teaching Methods}

As seen in Table 1, analysis yielded three meta-assumptions regarding required visual arts teaching methods. A substantial percentage of artists-teachers enacted or verbalized three main instructional methods: in-depth observation (33.7 percent, $n=55$ ); ongoing discourse, referring to participatory learning interactions (39.9 percent, $n=65$ ); and individual experience with a creative means of expression using materials (26.4 percent, $n=43$ ).

\subsubsection{Goals}

Goals were defined as the expected or desired results that the artists-teachers planned to achieve. Based on teachers' verbalizations and behaviors, the analysis identified four categories for teachers' implicit lesson goals (see Table 1).

The findings are based on the average duration of the goals components in emphasizing each component in each of the target groups. The relative duration of several goals appearing in one of the four groups of goals was measured during the class and 
it was found that Observational goals aimed to encourage students to arouse their thinking (58 percent), Technical goals aimed to teach students how to technique and implement skills (25 percent), Metacognitive goals aimed to arouse students' awareness and consciousness (11 percent), and Affective goals aimed to arouse students' emotions (6 percent).

\subsubsection{Process}

Process was defined as the expected or desired results that the artists-teachers planned to achieve. Based on teachers' verbalizations and behaviors, the analysis identified prices.

Here are some examples of how these processes were analyzed:

The teacher asks, "Michal, did you think of all the triangles? Can you share the way you thought of the idea? Can you describe what your thought process was?" - The process: reflection by reconstruction.

The teacher asks, "Did you finish? Any questions?" - The process: enhancing students' attention.

The teacher asks, "When you see the pictures, do you feel like making the connection? What do you feel?" - The process: encouraging emotions.

The teacher asks, "These are strong connections. Anybody feels the same way? From the way things are presented do you feel it speaks to you about freedom?" - The process: introspection following the creation.

Table 5. Artist-teachers' processes in teaching visual arts students, in descending order of behavior frequency $(\mathrm{N}=20)$

\begin{tabular}{llll}
\hline & Process & Frequency & Percentage \\
\hline 1 & Identification & 746 & 24.6 \\
2 & Focus & 539 & 17.8 \\
3 & Connection & 497 & 16.4 \\
4 & Increasing attention & 403 & 13.4 \\
5 & Reflection on reconstruction & 145 & 4.8 \\
6 & Generalization & 140 & 4.6 \\
7 & Arousal & 116 & 3.8 \\
8 & Reflecting difficulties & 103 & 3.5 \\
9 & Preservation & 97 & 3.2 \\
10 & Eliciting introspection & 69 & 2.4 \\
11 & Creation of individual processes & 69 & 2.3 \\
12 & Expansion & 65 & 2.2 \\
13 & Emotional regulation & 28 & 1.0 \\
14 & Review & 9 & 0.01 \\
\hline
\end{tabular}

As seen in Table 5, the analysis identified fourteen processes that the artist-teachers used to activate students during the lesson. Table 4 presents the frequencies and percentages for all of the processes identified. The four most common processes, in descending order, were: identifying an element (e.g., the teacher asked, "What visual elements are strong?" or, "Try to forget what you see, try to observe only this work") (24.6 percent), focusing (e.g., the teacher asked, "What is the direction of watching the art work?" (17.8 percent), pointing out connections, for example between the art work and the emotion feeling (e.g. the teacher asked if anybody feels that the connections are strong and whether freedom can be felt from the way things are presented) (16.4 percent), and increasing students' attention (13.4 percent).

\subsubsection{Correspondence of Lesson Activities with Meta-assumptions and Goals}

Different meta-assumptions and goals were prevalent during each of the three lesson patterns. During creative workshop activities, teachers assumed the importance of students' technical ability, emphasized the teaching method of individual experience in creative expression using materials, and highlighted technical goals. During reviewing activities, teachers assumed the importance of students' evaluative ability, emphasized the teaching method of ongoing interactive discourse, and highlighted metacognitive goals. During teaching of art-related topics activities, teachers assumed the importance of students' expansion of knowledge about arts, emphasized the teaching method of acquiring and assimilating outside knowledge, and highlighted cognitive goals. In addition, the teaching method of in-depth observation was prevalent during both the reviewing and the teaching of art-related topics activities. Affective goals and observational goals emerged to a small extent during all three lesson-activities.

\subsubsection{The Dynamic Circular Teaching Model}

Within this dynamic model, the teachers' meta-assumptions influence their goals, both meta-assumptions and goals direct the teachers' selection of processes various pedagogical activities, verbal and nonverbal segments, discourse modes acts and contents that are enacted at different times during the lesson. Thus, the implicit thinking in teachers' minds leads them to make decisions for explicit doing in the classroom, and then their understanding of students' reactions further influences their thinking, which results in a dynamic circular teacher-student-teacher and 
student-teacher-student interaction.

It was found that the teachers could use different parts of the meta-assumption that lead them during the different patterns of the lesson: in critique of students' artwork, in workshop, or in discussion of art-related topics. A "manova test" found that during critique of students' artwork, the teachers' meta-assumption is to develop meta-cognitive knowledge $(F(2,8)=15 / 25 \mathrm{p}<0.01)$ and therefore, the teachers develop reflection and observation during segments and acts that encourage meta-cognitive knowledge. During workshop, the meta-assumption of the teacher is to develop technique and skills knowledge $(\mathrm{F}(2,8)=6.85 . \mathrm{p}, 0 / 05)$. Finally, during discussion of art-related topics the teacher wanted to develop knowledge about art in general $(F(23,8)=7.01$. p, 0,01$)$, therefore, he thinks about goals that develop awareness to cultural information about art.

Figure 1 illustrates the dynamic cycles of interaction among the artists-teachers' implicit in-action mental models, their explicit behaviors as enacted in the lesson and the students' behaviors.

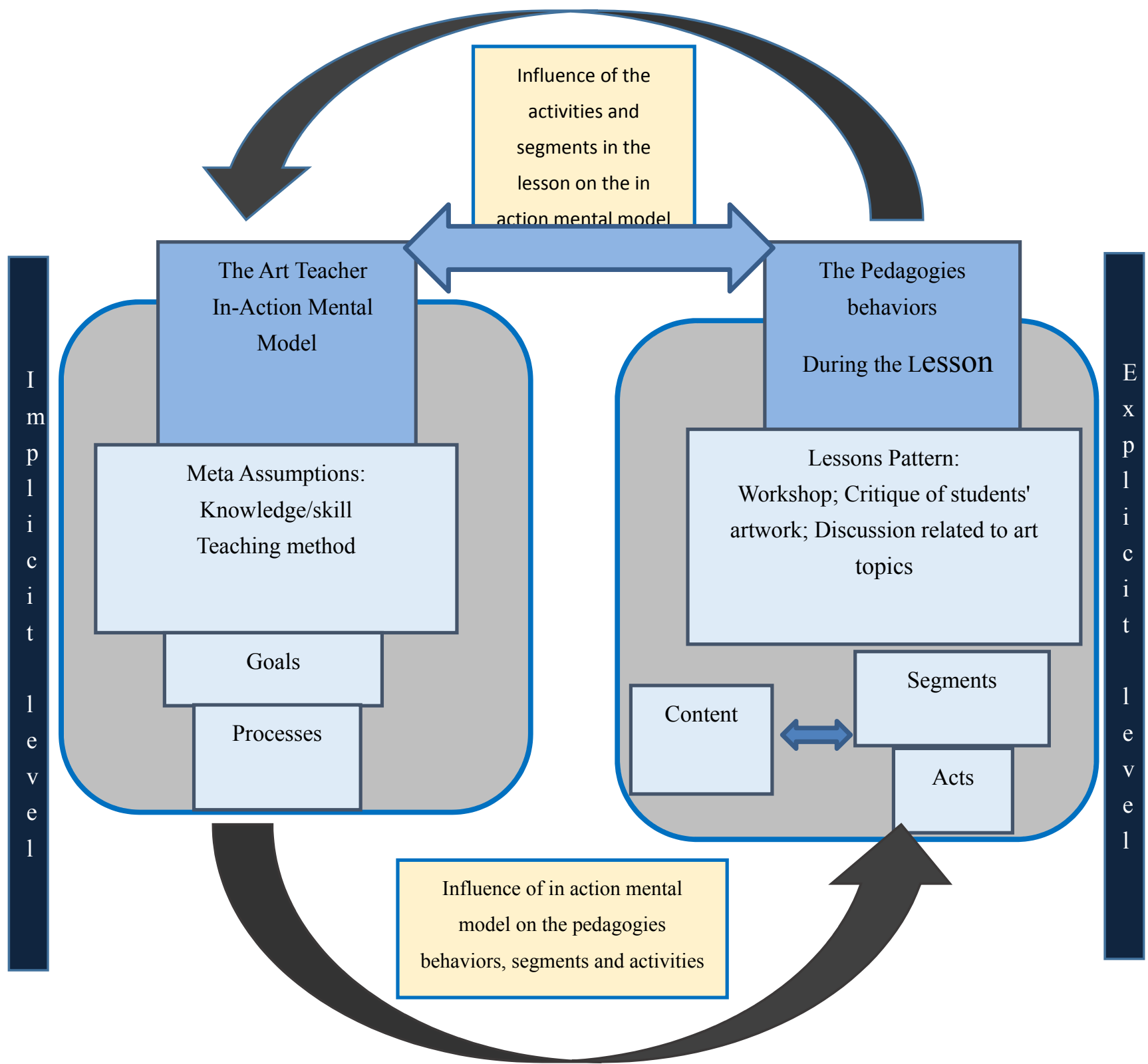

Figure 1. The dynamic circular teaching model 


\section{Discussion and Conclusion}

This research tested twenty teachers-artists teaching visual arts during full lessons (3-4 hours). The components of instruction were examined and interpreted into meta-assumptions, goals and process leading their teaching behavior in classes.

It was found that the art teachers have a mental model that characterizes their visual art class differently than previous mental models found in researches that examined other disciplines (Haim, Strauss \& Ravid, 2004; Mevorach, 2010; Mevorach \& Strauss, 2012).

As opposed to previous research (Haim et. al., 2004), whereas the Teaching Model may apply to all taught subject matters, the subject matter directly influences and shapes the in-action mental model of teachers. There is a distinct relationship between the discipline and the ways in which it is taught.

The answer to this finding can partly be found in the conclusions of Mevorach and Strauss's article (2012), which claimed that it is possible that only different parts of the general in-action mental model are activated during the teaching. In addition, Mevorach and Strauss (2012) claimed that it is possible to describe the same person's teaching through several in-action mental models of the learning and that it is these in-action mental models that guide the teacher's teaching. However, in this research, we claim that the teacher's mental model is influenced by the subject matter - visual arts. As evidence, the general mental model (Mevorach \& Strauss, 2012) does not include all the components of the in-action mental model of teachers teaching visual arts.

Haim et. al. (2004) asserted that the teachers' in-action mental model overpowers the taught subject matter (and not influenced by it as demonstrated in this research). They found this in-action mental model to be shared by teachers with diverse experience in teaching: pre-service teachers, beginning teachers and veteran teachers.

\subsection{What is the In-action Mental Model of Artists Teaching Visual Arts?}

We found that the mental model of artists teaching visual arts is a dynamic and circular model, the meta-assumptions, goals and process influence teachers' behaviors during the different lesson patterns (segments and acts) and activities that the student choose, influence the selection of different meta-assumptions, goals and process. This dynamic and circular model is the basic assumption about art. Eisner (2004) claims, that art is a process in which skills that differ from the scientific method are activated. These skills succeed in exposing significant existentialist insights through the artistic activity. In his opinion, the fallacy of the scientific method lies in its neglect of those aspects of teaching that are difficult to describe or that cannot be measured according to the experiments employed by the researcher. Visual arts have unique characteristics. The meta-assumptions and goals are connected to the subject matter taught by the teacher as a visual language, a place for personal expression and interpretation, and for communication with the language of art, which facilitates a greater understanding and awareness to the art history and culture we live and teach arts in.

\subsection{Contribution-implications and Directions for Future Research}

The theoretical contribution is to the field of In-Action Mental Model. This study focuses on clarifying the in-action mental model of art teachers teaching visual arts as a unique subject matter. Furthermore, this study is defining the boundaries of in action mental models that was identified in previous research (Haim, Strauss \& Ravid, 2004; Mevorach, 2010; Mevorach \& Strauss, 2012) by adding categories and discourse units.

On the pragmatic level - revealing a teacher's in-action mental model facilitates greater awareness to teachers teaching visual arts, that the teachers can use. Each teacher uses different parts of the in-action mental model discovered herein. The insights that the research indicated can contribute to teacher knowledge about learning and teaching art. The teacher must have a rich and abundant mental model about teaching art. Therefore, by interacting with other teachers' in action mental model and by understanding and mapping his and their in-action mental model, the teacher may learn from other teachers and expand his own use of his in-action mental model. Furthermore, the in-action mental model of teachers teaching visual arts presented in this research can serve as a frame of reference for self-criticism and self-evaluation in teaching in general and of visual arts specifically.

We live in a time when it is important to diversify and change the ways of teaching and learning so that it could reach all the students. For this reason only, the teachers in this study use parts of the mental model during one lessons. They have to change the pedagogy behavior in class, using more segments-contents modes, discourse modes observation and creation by using different and variable acts.

Since this study focused on visual arts, widening the categories of the in-action mental model by studies on other arts, such as dance, music, theater, and film is recommended. The characteristics of various types of arts subject matters may contribute to the understanding of the in-action mental model of teaching arts, and understand how these subject matters influence the in-action mental model, and the Teaching Model as a whole. As Darling-Hammond, Wei, \& Johnson 
(2009), and Darling-Hammond \& Haertel (2012) claimed, unique training programs are a necessary condition for development of the perceptions and comprehension of the future educational staff members.

\section{References}

Arnheim, R. (1966). Toward a psychology of art. Berkeley: University of California Press.

Arnheim, R. (1974). Art and visual perception. Berkeley: University of California Press.

Arnheim, R. (1989). Thoughts on art education. U.S.A: Getty Center for Education in the Art.

Arnheim, R. (1992). Sculpture the nature of a medium. In: To the rescue of art: Twenty-six essay (pp. 82-92). U.S.A.: California Press.

Ball, D. L., \& Forzani, F. M. (2011, Summer). Building a common core for learning to teach, and connecting professional learning to practice. American Educator, 35(2), 17-21, 38-39.

Ball, D. L., Thames, M. H., \& Phelps, G. (2008). Content knowledge for teaching: What makes it special? Journal of Teacher Education, 59(5), 389-407. https://doi.org/10.1177/0022487108324554

Berliner, D. (2005). The place of process-product research in developing the agenda for research on teacher thinking. In P. M. Denicolo \& M. Kompf. (Eds.), Teacher thinking and professional action (pp. 3-16). London and New York: Routledge.

Bishop, R. (2005). Freeing ourselves from neocolonial domination in research. In N. K. Denzin \& Y. S. Lincoln (Eds.), The Sage handbook of qualitative research (Third Edition) (pp. 109-138). London: Sage Publications.

Bower, M., Cavanagh, M., Moloney, R., \& Dao, M. M. (2011). Developing communication competence using an online video reflection system: Pre-service teachers' experiences. Asia-Pacific Journal of Teacher Education, 39(4), 311326. https://doi.org/10.1080/1359866X.2011.614685

Braden, T. A., \& Hortin, J. A. (1982). Identifying the theoretical foundation of virtual literacy. Journal of Visual Vernal Langaging, 2, 37-42. https://doi.org/10.1080/23796529.1982.11674354

Bresler, L., Grauer, K., \& Powell, K. (Eds.). (2014). Special issue: In memoriam - Elliot Eisner. International Journal of Education \& the Arts, 15(SI1). Retrieved from: http://www.ijea.org/v15si1/

Charmaz, K. (2005). Grounded theory in the $21^{\text {st }}$ century. In N. K. Denzin \& I. S. Lincoln (Eds.), The Sage book of the qualitative research (Third Edition) (pp. 507- 536). Thousand Oaks, London \& New Delhi: Sage Publications.

Charteris, J., \& Smardon, D. (2013). Second look-second think: A fresh look at video to support dialogic feedback in peer coaching. Professional Development in Education, 39(2), 168-185. https://doi.org/10.1080/19415257.2012.753931

Cochran-Smith, M., \& Villegas, M. (2015). Framing teacher preparation research: An overview of the field, Part I. Journal of Teacher Education, 66(1), 7-20. https://doi.org/10.1177/0022487114549072

Danielowich, R. M. (2014). Shifting the reflective focus: Encouraging student teacher learning in video-framed and peer-sharing contexts. Teachers and Teaching: Theory and Practice, 20(3), 264-288. https://doi.org/10.1080/13540602.2013.848522

Darling-Hammond, L., \& Haertel, E. (2012). A better way to grade teachers. Los Angeles Times. Retrieved from http://www.latimes.com/news/opinion/commentary/la-oe-darling-teacher

Darling-Hammond, L., Wei, R. C., \& Johnson, C. M. (2009). Teacher preparation and teacher learning: A changing policy landscape. In G. Sykes, B. L. Schneider \& D. N. Plank (Eds.), Handbook of education policy research (pp. 613-636). New York: American Educational Research Association and Routledge.

Denzin, N. K., \& Lincoln, Y. S. (2005a). Introduction: The discipline and practice of qualitative research. In N. K. Denzin \& Y. S. Lincoln (Eds.), The Sage handbook of qualitative research (Third Edition) (pp. 1-31). London: Sage Publications.

Donoghue, D. O. (2009). Are we asking the wrong questions in arts-based research? Studies in art education. National Art Education Association A Journal of Issues and Research, 50(4), 352-368.

Eisner, E., \& Day, M. (Ed.). (2004). Handbook of research and policy in art education. London: Lawrence Erlbaum Associates.

Flood, J., Brice, H. S., \& Lapp, D. (Eds.). (1997). Handbook of research on teaching literacy through the communicative and visual arts. NY: Erlbaum.

Goodman, N. (1976). Languages of art. Indianapolis, IN: Hackett. 
Haim, O., Strauss, S., \& Ravid, D. (2004). Relations between EFL teachers' formal knowledge of grammar and their in-action mental models of children's minds and learning. Teaching and Teacher Education, 20, 861-880. https://doi.org/10.1016/j.tate.2004.09.007

Huss, E. (2008). Shifting spaces and lack of spaces: Impoverished Bedouin women's experience of cultural transition through art-based research. Visual Anthropology, 21, 58-71. https://doi.org/10.1080/08949460701688973

Johnson-Laird, P. N. (1983). Mental models: Towards a cognitive science of language, inference, and consciousness. Cambridge, MA: Harvard University Press.

Johnson-Laird, P. N. (2001). Mental models and deduction. Trends in Cognitive Sciences, 5(10), 434-441. https://doi.org/10.1016/S1364-6613(00)01751-4

Jones, N. A., Ross, H., Lynam, T., Perez, P., \& Leitch, A. (2011). Mental models: An interdisciplinary synthesis of theory and methods. Ecology and Society, 16(1), 46. https://doi.org/10.5751/ES-03802-160146

Kitayama, S., \& Cohen, D. (Eds.). (2010). Handbook of cultural psychology. Guilford Press.

Langer, S. (1969). The work of art as a symbol. In: J. Hospers (Ed.), Introductory readings in aesthetics (pp. 171-184). New York: The free Press.

Lee, K., \& Johnson, A. S. (2007) Child development in cultural contexts: Implication of cultural psychology for early childhood teacher education. Early Childhood Teacher Education, 35, 233-243. https://doi.org/10.1007/s10643-007-0202-7

Lynam, T., \& Brown, K. (2012). Environment interactions: Theory, policy implications, and methodological explorations. Ecology and Society, 17(3), 24. https://doi.org/10.5751/ES-04257-170324

Manrique, M., \& Abchi, S. V. (2015). Teachers' practices and mental models: Transformation through reflection on action. Australian Journal of Teacher Education, 40(6), 13-32. https://doi.org/10.14221/ajte.2015v40n6.2

Maxwell, J. A., \& Loomis, D. M. (2003). Mixed methods design: An alternative approach. In A. Tashkkori \& C. Teddlie (Eds.), Handbook of mixed methods in social and behavioral research (pp. 241-272). Thousand Oaks, CA: Sage.

Mayer, R. E. (1983). Knowledge and thought: Mental models that support scientific reasoning. In: P. N. Johnson-Laird (Ed.), Mental models: Towards a cognitive science of language, inference, and consciousness (pp. 226-310). Cambridge, MA: Harvard University Press.

Mevorach, M. (2010). The magic of learning. In: M. Mevorach \& G. Russo-Zimet (Eds.), The learning mind (pp. 23-55). Jerusalem: The Hebrew University Magnes Press [ in Hebrew].

Mevorach, M., \& Strauss, S. (2012). Teacher educators have different in-action mental models in different teaching situations. Teachers and teaching: Theory and practice, 18(1), 25-41. https://doi.org/10.1080/13540602.2011.622551

Moray, N. (1999). Mental models in theory and practice. In: D. Gopher \& A. Koziat (Eds.), Attention and performance (pp. 223-258). Cambridge: MIT XV11 Massachusetts.

Noldus, L. P., Trienes, R. J., Hendriksen, A. H., Jansen, H., \& Jansen, R. G. (2000). The Observer. Video-Pro: New software for the collection, management, and presentation of time-structured data from videotapes and digital media files. Behavior Research Methods, Instruments \& Computers, 32, 197-206.

Norman, D. (1983). Some observations on mental models. In: D. Genter \& A. L. Stevens (Eds.), Mental models (pp. 7-14). Hillsdale, NJ: Erlbaum.

Palmunen, L. M., Pelto, E., Paalumäki, A., \& Lainema, T. (2013). Formation of novice business students' mental models through simulation gaming. Simulation \& Gaming, 44, 846-868. https://doi.org/10.1177/1046878113513532

Ratcliff, D. (2003). Video methods in qualitative research. In P. M. Camic, J. E. Rhodes, \& L. Yardley (Eds.), Qualitative research in psychology. Expanding perspectives in methodology and design (pp. 113-129). Washington, D.C.: American Psychological Association. https://doi.org/10.1037/10595-007

Schön, D. A. (1983). The reflective practitioner: How professionals think in-action. London: Temple Smith.

Schön, D. A. (1987). Educating the reflective practitioner. San Francisco: Jossey-Bass.

Schön, D. A. (1988). Coaching reflective teaching. In P. D. Grimmett \& G. L. Erickson (Eds.), Coaching reflective teaching (pp. 19-29). New York: Columbia University Press.

Schutz, A. (1970). On phenomenology and social relations. U.S.A: Chicago Press.

Strauss, S. (2001). Folk psychology, folk pedagogy and their relations to subject matter knowledge. In B. Torff \& R. S. 
Sternberg (Eds.), Understanding and teaching the intuitive mind (pp. 217-242). Mahwah, NJ: Erlbaum.

Strauss, S. (2005). Teaching as a natural cognitive ability: Implications for classroom practice and teacher education. In D. Pillemer \& S. White (Eds.), Developmental psychology and social change (pp. 368-388). New York, NY: Cambridge. https://doi.org/10.1017/cbo9780511610400.016

Vosniadou, S., Baltas, A., \& Vamvakoussi, X. (Eds.). (2007). Re-framing the conceptual Change approach in learning and instruction. Advances in learning and instruction series. Elsevier Science.

Yaakobi, D., \& Sharan, S. (1985). Teacher beliefs and practices: The discipline carries the message. Journal of Education for Teaching, 11, 187-199. https://doi.org/10.1080/0260747850110207

\section{Copyrights}

Copyright for this article is retained by the author(s), with first publication rights granted to the journal.

This is an open-access article distributed under the terms and conditions of the Creative Commons Attribution license which permits unrestricted use, distribution, and reproduction in any medium, provided the original work is properly cited. 